IZA DP No. 4547

The Unknown Immigration:

Incentives and Family Composition in Inter-Country Adoptions to the United States

Fernando Antonio Lozano

Sherrie A. Kossoudji

November 2009 


\title{
The Unknown Immigration: Incentives and Family Composition in Inter-Country Adoptions to the United States
}

\author{
Fernando Antonio Lozano \\ Pomona College \\ and IZA \\ Sherrie A. Kossoudji \\ University of Michigan \\ and IZA
}
Discussion Paper No. 4547
November 2009

\author{
IZA \\ P.O. Box 7240 \\ 53072 Bonn \\ Germany \\ Phone: +49-228-3894-0 \\ Fax: +49-228-3894-180 \\ E-mail: iza@iza.org
}

\begin{abstract}
Any opinions expressed here are those of the author(s) and not those of IZA. Research published in this series may include views on policy, but the institute itself takes no institutional policy positions.

The Institute for the Study of Labor (IZA) in Bonn is a local and virtual international research center and a place of communication between science, politics and business. IZA is an independent nonprofit organization supported by Deutsche Post Foundation. The center is associated with the University of Bonn and offers a stimulating research environment through its international network, workshops and conferences, data service, project support, research visits and doctoral program. IZA engages in (i) original and internationally competitive research in all fields of labor economics, (ii) development of policy concepts, and (iii) dissemination of research results and concepts to the interested public.
\end{abstract}

IZA Discussion Papers often represent preliminary work and are circulated to encourage discussion. Citation of such a paper should account for its provisional character. A revised version may be available directly from the author. 
IZA Discussion Paper No. 4547

November 2009

\section{ABSTRACT \\ The Unknown Immigration: Incentives and Family Composition in Inter-Country Adoptions to the United States}

Children adopted from abroad are an immigrant group about which little is known. According to the U.S. Census more than one and a half million children living in the U.S. are adopted, with fifteen percent of them born abroad. In fact more than twenty thousand adopted orphans from abroad enter the country each year. The families who adopt these orphans are mostly white, wealthy, and well educated (Kossoudji, 2008). What are the characteristics of children who are adopted from abroad and what incentives drive families to adopt them? In this paper we use the 2000 census to illuminate the landscape of international adoption. We address three issues: 1) How do the demographic characteristics of the children adopted from abroad change as other countries open and shut the door to inter-country adoptions, changing the supply of available children? 2) U.S. born parents and foreign-born parents may have different incentives to adopt. How are these incentives reflected in the characteristics of the children they adopt? 3) What explains differences in the estimates of foreign-born adopted children in the Census and the number of visas granted by the State Department?

JEL Classification: $\quad \mathrm{J} 13, \mathrm{~J} 12$

Keywords: immigrant children, international adoption

Corresponding author:

Fernando A. Lozano

Department of Economics

Pomona College

425 N. College Ave

Claremont, CA 91711

USA

E-mail: fernando.lozano@pomona.edu 


\section{Introduction}

According to the U.S. Census more than one and a half million children under the age of eighteen living in the U.S. are adopted. Fifteen percent of these children were born abroad. While the adoption of foreign-born children was a relatively isolated occurrence early in the century, the number of foreign-born adopted children arriving in the United States on adopted orphan visas rose from just over 8,000 in 1989 (the first year of national data collection) to more than 18,000 in 2000 , the year of the census. The inflow of these foreign-born children has reshaped the composition of the average American family, especially as adoption has been used as a means for family formation among parents unable to have their own children (Bachrach, 1983). In this paper we explore the changing supply of children from different countries, the characteristics of children adopted from abroad, and how these characteristics vary across parents with different characteristics.

Unsurprisingly, economists and other social scientists have paid attention to the outcomes of children adopted from abroad (see, for example, Sacerdote, 2007; Plug, 2004). Yet this literature does not discuss any supply issues. In this literature it is assumed that all parents wishing to adopt from abroad face similar costs and incentives; and will pursue a certain set of characteristics in children. Implicitly, adopting parents search for characteristics that will successfully lead to "family formation". For example, these characteristics may be age or the gender of the adopted child. There are two reasons why very young children are more appealing among adopting parents: first, when parents adopt they want to maximize the lifetime utility derived from parenting, and more time as a parent increases utility. 
Second, children adopted at an older age may have more exposure to the effects of an adverse background. Brooks et al. (2002) report that $85 \%$ of prospective adopting parents are willing to adopt a child two years or younger, while only $45 \%$ are willing to adopt a child over six years old. But parents may face very different incentives and costs when adopting from abroad, and these differences will yield systematic differences in the adoption process and in the characteristics of the children adopted. Parents may choose to adopt for humanitarian reasons (child centered reasons), for example, an incentive that is not discussed in this literature, and may find adopting older children more satisfactory.

We find that there are very clear differences between adopting parents born in the United States and those born abroad in their adopting choices. While the former tend to adopt babies and infants, the latter tend to adopt older children. In addition, foreign-born parents who adopt children from their own birth country adopt children who are, on average, older than those adopted by other foreign-born parents. These results can be puzzling if we only consider the family formation incentives outlined above. Our evidence suggests that U.S. born parents do appear to respond to the incentives that lead to family-formation adoption. In contrast, foreign-born adopting parents may have different incentives to adopt children, be it that these parents face social pressures from their communities of origin or have an altruistic utility function, which is maximized by adopting older children from their communities of origin. The contributions of these paper are three-fold: first, we document that parental characteristics are important determinants of adopted children's characteristics, especially different parent characteristics that are 
associated with different child's age at adoption; second, we explore how these characteristics vary across time between 1983 and 2000; third we consider supply issues and the validity of using the census to talk about foreign born adoptions by comparing the estimates of the number of adopted children using the 2000 Decennial Census, with the number of visas granted by the US Department of State.

\section{The 2000 Census and Adopted Children}

We use the 5\% sample of the 2000 U.S. Census for the data in this paper. The 2000 census asked, for the very first time, the relationship status of the head of the household to any adopted children in the household. Before the 2000 census, biological children were indistinguishable from adopted children. We restrict our sample to adopted children under the age of 18. In the 2000 census there were 59.8 million biological children, 1.6 million adopted children, and 3.3 million stepchildren under the age of eighteen living with householders in the United States. To investigate only foreign-born adoptees, we use additional information from the census. The census provides information on the place of birth for all individuals and, for those born abroad, the year the immigrant arrived in the United States. The actual date of adoption is not enumerated in the census. Using the immigration information, we infer the age, and year, at which a child born abroad was adopted by assuming that the year the child entered the United States is the year of adoption. We do not know if a foreign born child was actually adopted some time before immigrating to the United States, so the year of adoption we estimate may be later than the actual adoption took place. In many cases this is only a minor problem as 
many children adopted from abroad are adopted as infants or toddlers. Because we focus on inter-country adoptions we exclude from the sample all adopted children born abroad whose parents were born abroad as well and whose year of immigration is the same as either parent. In some analyses, we compare the age of adoption in different years. Since older children have aged out of the household, and children adopted at older ages in earlier years will have already left the household, we restrict the years of analysis in those cases. While the census is not the optimal data set to examine changes in adoption over time because of this problem, it affords us a first glimpse of changing adoption in the United States during a critical period of its growth.

\section{The Demography of Adoption}

Figure 1 shows the number of adopted foreign-born children by year of birth, and the number of adopted foreign-born children by year of immigration. We include both the year of birth and the year of immigration in Figure 1 because we do not know the exact time of adoption. The number of adopted foreign-born children who immigrate each year increases throughout the entire period and skyrockets after 1993. For the earlier years, the low numbers may be an artifact of the data, as children who were adopted in the earlier years are much more likely to be over the age of 18 and/or not living in the household during the 2000 census. Thus, the number of foreign-born adoptions recorded in the U.S. 2000 Census is an underestimate of the actual number of adoptions during each recorded year. However, the growth of adoptions in the 1990s is a real trend. The number of U.S. 
visas for adopted children rose throughout the decade because changes in the adoption laws in China, Guatemala, and elsewhere. This positive supply shock allowed American families to find the doors for the adoption of young children in many countries open .

In summary, Figure 1 shows that the age distribution for children born abroad is much more uniform than the time of migration, indicating that (of the children in the household at the time of the census) children were adopted at different ages. Even though the adoption of babies from abroad is the stereotype, older children are adopted as well.

\section{Foreign Born Adoption and Adoptive Parents' Birthplace}

Children who are adopted from abroad have always been in a unique citizenship category and granted citizenship more readily than most other immigrants. Practice was codified recently with the Child Citizenship Act of 2000, which means that citizens who wish to adopt abroad have the right to petition for the immediate immigration of a child adopted abroad. If the adoption is finalized abroad, the child becomes a citizen upon entry to the United States using the IR3 visa. If the adoption is finalized in the United States, the child enters the United States on an IR4 visa and becomes a citizen automatically when the court issues the final adoption decree. Legal residents, however, must petition for immigration under family preferences, which could take years, although there are exceptions: ${ }^{1}$

\footnotetext{
1 "The U.S. Department of State has clarified that U.S. permanent residents may petition for their adopted alien child to immigrate as a qualified derivative only if they completed the adoption prior to their admission as lawful permanent residents. In other words, only children who were adopted before their
} 
Adopted children of legal residents can petition for citizenship after the age of eighteen.

Potential parents may have different incentives to adopt. Most economists think of the time spent with one's adopted children as a normal good, and so the more advanced age the adopted child is, the lower will be the present value of the utility derived from adopting. As a result, parents who adopt have incentives to adopt children at as young an age as possible. The prevalence of foreign-born babies adopted by parents in the United States speaks of these incentives. Parents who are born in the United States are likely to fit the model of the infertile couple or the couple driven by charity incentives to adopt a young child from abroad. But the incentives for adoption may rest on different factors for foreign-born parents in the United States. Parents who were born abroad and immigrated to the United States may also have incentives to adopt based on family or community obligations in the home country or on altruistic motives related to the home country. These obligations or motives loosen the tie between the age of the child and utility or benefits from time spent with the child.

As a result, there are two principal sources of adoption of children born abroad and the census data show how those two kinds of adoption reflect the characteristics of the adults who adopt them. More than three-quarters of the children adopted from abroad are adopted by parents who were both born in the United States. Parents born in other countries also adopt children from abroad and

parent became a Green Card holder and who satisfy the three requirements for adoption: (i.e., (1.) adoption before the age of 16; (2) two years custody by their adoptive parent; and (3) two years of residence with the parent) may immigrate into the U.S. together with their parent as a derivative." Again, these children are excluded from the sample. 
households where at least one parent is foreign-born are responsible for onequarter of all children adopted from abroad. These two kinds of households, however, have very different adoption patterns. Figure 2 shows the age of birth and the year of immigration for children adopted by two U.S. born parents (Panel 1) and those adopted by least one parent who is foreign born (Panel 2). Single parents without partners are included in each panel by country of birth. The year of birth and the year of immigration are very similar in Panel 1 when the parents are both U.S. born. Children adopted by two U.S. born parents are adopted at an average age of three years old. Immigration numbers rise along with birth date. Large numbers of children born in a year are associated with large number of children immigrating in a year with a possible small lag. The small dip in the number of births in the years just before the census year indicates that babies only from those birth years have already been adopted. In the second panel of Figure 2, however, birth year and immigration year move in opposite directions. The number of children immigrating each year rises but the number born in each year falls over time for these children. There is a high proportion of adopted children in the 2000 census who were born in the 1980s. But the highest proportion of immigrant children came in the late 1990s. Children adopted by foreign-born parents are older. In fact, the average age of foreign-born children at adoption when at least one parent is foreign born is more than five and a half years old.

Parents who are born abroad may have incentives to adopt that are systematically different from those of parents born in the United States. They, too, may or may not have fertility problems. They may adopt a child because of the 
death of a relative. In addition, they may have family or community obligations or be subject to pressure by people from home to adopt a child to give him or her a better life. They may simply feel more altruistic toward children from their home country and adopt for the same humanitarian reasons but with a more targeted focus. As a result, two-thirds of the children adopted by foreign-born parents come from their home country. The next figure, Figure 3, shows the same trends as Figure 2 but for foreign-born parents who adopt from the home country and foreign-born parents who adopt from a different country. While both groups of parents adopt children who are older, on average, than those adopted by U.S. born parents, those adopted from the home country are much older than those adopted from a different country. The average age of adoption is six and a half years old for the former, but less than four years old for the latter.

Figure 4 documents this crucial difference in the age at adoption of children adopted by foreign-born parents and U.S. born parents. First notice that, just as in the other graphs, an artifact of the data is that the levels of adoption are truncated for higher ages. But the shape of the adoption patterns still shows through in this graph. The difference in the ages of adoption for foreign-born adopted children are stark when comparing parents when both born in the United States and parents when neither is born in the United States. When both parents are U.S. born, nearly one-half of all the adopted children are babies at adoption. Another 18 percent are age one and 10 percent are age two. Over 84 percent of children are adopted at age five or below. After that, there is a low but similar percentage across the ages. Families with at least one parent U.S. born have kids with similar characteristics, but 
with a slightly lower percentage of infants adopted. In contrast, when both parents are foreign-born, only 14 percent of the adoptees are infants and 10 percent are adopted at age one, and there are large numbers of children adopted at all ages. More than 50 percent of children are adopted at age six or above. In summary, Figures 2 to 4 show stark differences between the age characteristics of children adopted by U.S. born parents and children adopted by parents born abroad living in the United States. As a result, inter-country adoption, itself, needs to be considered separately depending on the birthplace and incentives of the parents who adopt.

\section{Country Policy and the supply of children-Country of birth}

The characteristics of cohorts of adopted children present a picture of geopolitics and country disaster. Large scale adoption began after WWII as Americans adopted children from war torn Europe and Japan, and Korean adoption followed the Korean War. The newest wave of inter-country adoption, however, while a relatively small component of overall immigration, is significant because country specific policies can have such a large impact on the source countries of adopted orphans. These adopted babies and young children come in waves from specific countries in response to events or policy changes in those countries. Figure 5A shows the State Department's visa entrants for all years between 1989 and 2008. ${ }^{2}$ Figure 5B shows foreign born adopted children in the 2000 Census who arrived in the United States between 1984 and 1999.

\footnotetext{
2 The ten countries that accounted for the largest number of adopted orphan visas during the census period (1989-1999) are individually documented in Figure 5A. This is not the same set of countries that accounted
} 
Often, singular events or policies change the character of inter-country adoption. As noted, Korea has been a source of adopted orphans since the Korean War. Korea was still responsible for 44 percent of all foreign-born adoptees in 1989. That year, the Korean government, responding to democratization and negative publicity about the large numbers of children adopted and sent abroad, vowed to reduce, and eventually eliminate, adoptions of Koreans by people from other countries. This policy was not completely successful, but as Figure 5A shows, adoptions from Korea went from 44 percent of all adoptions to 12 percent of all adoptions in just ten years. Over the twenty-year period, as the number of adoptions from all countries increased, both the percentage and the number of adoptions from Korea decreased. Less than one-third as many children were adopted from Korea in 2008 than twenty years before even though overall adoption more than doubled. Similarly, the overthrow of Nicolae Ceausescu of Romania in 1991 was accompanied by publicity about "thousands of children" in understaffed orphanages because of population expansion policy. ${ }^{3}$ U.S. adoptions from Romania, numbering only a couple of hundred before 1991, rose to 2,594 during 1991, making Romanians 31 percent of foreign-born adopted orphans in 1991. Immediately, cries of widespread corruption and the discovery of problems among Romanian children who were adopted led to a temporary moratorium on inter-country adoptions from Romania at the end of 1991. As a result, almost no Romanian children were adopted in 1992 or 1993. Attempts to promote both inter-country adoption and local social services

\footnotetext{
for the largest number of visas during the entire period up to 2008 as country policy increased or decreased the number of children available to be adopted by parents in the United States.

${ }^{3} \mathrm{http} / / / \mathrm{www}$.adoptioninstitute.org/FactOverview/international.html
} 
led to increases in adoption from Romania until a harsher moratorium was put through after the 2000 census and adoptions from Romania were virtually halted.

Romanian adoption was replaced by adoption from other countries. Although there was almost no adoption from Russia or the Soviet satellites before 1992, the break-up of the Soviet Union was responsible for a tidal wave of adoption from the former satellites and Russia, itself. As orphanages filled to capacity, Russia opened its doors to international adoption. So did Kazackstan, Ukraine, and Bulgaria and other soviet satellites. All show a growing stream of children adopted in the United States. By the late 1990s, over one-third of all foreign-born adopted orphans come from the former Soviet Union.

Expansionary policy within countries was a haphazard process, probably responding to the emergence of nascent adoption networks and local state needs and issues. There was essentially no adoption from mainland China until 1992, when the Chinese government passed The Adoption Law of the People's Republic of China that allowed international adoptions. China had an abundance of adoptable girls, probably as a result of the one-child policy and families within China preferred boys and so there was little adoption demand for girls. Adoption from China jumped from 0.7 percent of the total in 1991 to 29.4 percent in 1996 and China remains the largest country grouping of foreign-born adoptions. Guatemala is one of the few countries that allows single parents to adopt and adoption from Guatemala grew throughout the period. Although Guatemala was a relatively low percentage of visas before the 2000 census, Guatemalan orphans play a much larger role after the census. 
Importantly, Figure 5A, from State Department Visas, and Figure 5B, from the U.S. Census, shows similarly high percentages of children coming from three major source countries: Korea, China and Russia. There is a significantly higher percentage of Korean children in the census data. These figures do differ especially, however, in the number of adopted children from three countries that are traditional labor exporting economies to the United States: Mexico, Guatemala, and the Philippines.

We now know that the birthplace of the parents matters for the birth country of the adopted child as well. To further explore these differences, Figure $5 \mathrm{C}$ and Figure 5D divide the sample again by nativity of the parents, where Figure 5C documents households with both parents U.S. born and Figure 5D documents those children adopted by foreign-born parents. When both parents are U.S. born, the source country distribution follows the history of inter-country adoption and country supply. This figure clearly identifies other countries' policies. Between twothirds and 89 percent of children are from the top ten sending countries and most of the adoptions come from Korea, China, and Russia. But when parents are foreignborn, the source country distribution appears more like the source country distribution for immigrants to the United States. The countries highlighted in Figure 5D are different from Figure 5C; while Mexico, the Philippines, El Salvador and Dominican Republic are barely featured in Figure 5C, these countries are featured predominantly in Figure 5D.

As a result of the different incentives for U.S. born and foreign-born parents and the ways that children they adopt may gain entry to the United States, visa statistics from the State Department may underestimate the number of foreign-born 
adopted children entering the country each year. While there may be recall error in the census about the exact timing of adoption and immigration to the United States, these census data represent the best estimates of adoption trends. In Figure 6, we compare the adopted foreign-born orphan visas for each year with the number of adoptions reported to have immigrated each year by families reporting in the 2000 census. Even though the census numbers are underestimates because of aging out, there are many, many more adoptions in the census than in the visa figures.

Although the two series start out similarly (the visa statistics are only available from 1989) there is a divergence in the early 1990s that grows substantially until there are thousands more children immigrating in each year according to the census data than the visa data. Given that these are not foreign-born children who immigrated with their adoptive parents and that the census data are underestimates, even in these years close to the census, the large differences in these numbers indicate that we still do not have good estimates of the number of foreign-born adopted children who immigrate each year.

\section{Parents' Characteristics and the Characteristics of Adopted Children}

Next we explore how the characteristics of the adopting parents correlate to the age when the child was adopted. Table 1 presents the demographic characteristics of adopting parents. We divide the data into the three different categories reflected in Figure 1 to Figure 4. The first column presents sample means for parents who were born in the U.S., the second column presents the sample means of parents in households where at least one parent was born abroad and who 
adopted in their birth country, and the third column presents the sample means of parents born abroad (at least one) and who adopted from a different country than their birth country.

The first row presents the estimated age of the mother and father when the child was adopted. There are only small differences in the estimated age categories: as foreign-born parents adopting in a different country to their place of birth are, on average, the eldest at the time of adoption. They are followed by parents born in the U.S. , and trailed by parents born abroad who adopt children in their birth country. The second and third rows present the proportion of mothers and fathers respectively who graduated from college. Foreign-born parents who adopt in their country of birthplace are half as likely to graduate from college than other parents adopting abroad. More than one-half of the mothers and fathers who are U.S. born or who do not adopt from their country of origin are college graduates.

Table 1 also includes some labor market information of adopting parents. The fourth row documents the household's 1999 annual income; again foreign-born parents who adopt in their own country earn less than 65 percent of what other adopting parents earn. Since adoptions occurred at different times, and we only see earnings outcomes in 1999, this income does not represent a good comparison of income differences if foreign-born parents adopted children at a different time or at a different age than US born parents. To help assess income differences, the estimates in the fifth row control for age differences by showing the estimate of the 
household earning's percentile within 7 age groups ${ }^{4}$, this is a number between 0 (lowest earners) and 100 (highest earners) and represents the household position in the income distribution of the head's age group. Again, the average foreign born parents' earnings adopting in their home country fall in the $55^{\text {th }}$ percentile, while the average foreign born parents earnings adopting in a different country are at the 70 percentile. The average U. S. born parents' earnings are in the $73^{\text {rd }}$ percentile. Parents who adopt children from their home country earn less than other parents who adopt from abroad.

Table 1 also includes information on family composition. The sixth and seventh rows document the proportion of adopting households with a single parent (these include divorced and separated parents). There are not many significant differences across parent groups: typically about one in six adopting families consists of a single parent. Finally, foreign-born parents are more likely than U.S. born parents to have their own biological children at the time of adoption, About 20 percent of those adopting from their home country and 19 percent of those adopting from a different country have their own biological children in the household. Only 16 percent of U.S. born parents do. But looking at all children in the household reverses that comparison. U.S. born parents and foreign-born parents who adopt from a different country are more likely to have children in the household than foreign born parents who adopt from the home country.

\footnotetext{
4 The age groups for adopting parents are: less than 25, 25-29, 30-34, 35-39, 40-44, 45-49 and 49+. The results are similar if instead we use earnings adjusted for age when the child was adopted.
} 
Table 2 documents the characteristics of all foreign-born adopted children using the same column groups as in Table 1 . The first row presents the average child's age when adopted. Children adopted by U. S. born parents, are adopted on average at age three. Children adopted by parents who were born in the same country are adopted on average at 6.5 years of age. Children adopted by foreignborn parents adopted in a different country than the parents' birthplace are adopted on average at 3.7 years of age. There are also differences on the gender of the adopted child; parents that adopt from their home country are slightly less likely to adopt girls than all other parents. Foreign-born parent who adopt from their home country are much more likely to adopt a child with Hispanic ethnicity: almost one half of those parents adopt a Hispanic child. In contrast, only 20 percent of other parents adopt an Hispanic child. Similarly, parents adopting intheir birth country are much more likely to adopt a child who is black. While there are many characteristics of adoptive parents that are similar, the sample means above highlight that they come from different income and educational experiences and they adopt children with different characteristics.

As we argue in this paper, an important characteristic of adopted children, and an important difference of the adoption for parents who are born in the United States or abroad is the age of the child when he or she is adopted. What demographic characteristics determine the age at which a child is adopted? While we cannot speak to overall supply of children looking to be adopted by age, we can look at the age of adopted children and the way that parents' characteristics correlate to the age of adoption. To understand how parents' characteristics 
correlate with the age when the child was adopted we estimate the following linear regression model:

$$
A_{i t}=\theta_{1} X_{i t} \times U S_{i t}+\theta_{2} X_{i t} \times S C_{i t}+\theta_{3} X_{i t} \times D C_{i t}+C^{\prime} \beta+Y^{\prime} \gamma+\varepsilon_{i t}
$$

where $\mathrm{A}$ is the estimated age of adoption for the child, $X_{i t}$ is a vector of parents demographic characteristics and includes the mother's age when adopted, whether the mother is a college graduate, whether the mother is a single parent, the age adjusted household income percentile and whether other children were present in the household at the time of the adoption ${ }^{5}$. These characteristics are interacted with three different indicator variables: $U S_{i t}, S C_{i t}$ and $D C_{i t}$ which stand for U. S. born parents, for foreign born parents adopting in the same country as they were born, and for foreign born parents adopting in a different country respectively. $\theta_{1}, \theta_{2}$ and $\theta_{3}$ are vectors of parameters associated with each interaction term between the parents' characteristics and the parents' birthplace. The vector $C$ contains fixed effects for Korea, China, Russia, Mexico, India, Colombia, Guatemala, Romania and Philippines, and the vector $Y$ represents year fixed effects (neither of which is interacted with parent characteristics). When estimating this regression we only include observations of children adopted in 1990 or later, as potentially some of the children adopted before are already out of the household by the year 2000; the results are robust to whether we include children adopted before 1990 or not.

The estimates for the coefficients in equation 1 are presented in Table 3. Recall that in this equation each parent characteristic is interacted with the dummies $U S, S C$ and $D C$. The first column presents the estimates of the coefficients

${ }^{5}$ For households without mothers, the information for the father is used. 
for the interactions between each characteristic and US. The second column presents the estimates of the coefficients for the interactions with $S C$, and finally the third column presents the estimates for the interactions with $D C$. The bottom panel presents the estimates for each country fixed effect ${ }^{6}$. The omitted category is all U. S. born parents adopting abroad, hence all estimates are relative to this group. The estimates in the first row confirm the results from Figures 1-4, that is, controlling for mother's demographic characteristics foreign-born parents adopt children who are olden than children adopted by U. S. born parents. When the parents adopt in their home country, children are conditional on other demographic characteristics, almost 8 years older at the age of adoption than children adopted by U. S. born parents - recall that the sample includes only children who migrated at a different time than either parent. Conditional on other demographic characteristics When foreign-born parents adopt in a different country, their children are on average, almost 4 years older at age of adoption than children adopted by U. S. born parents.

Older mothers tend to adopt older children, yet the relationship between the age of the mother and the age of the child is almost three times stronger for mothers who are U.S. born than for foreign-born mothers who adopt in their birth country. That is, the link between mother's age and child's age, while significant for foreignborn parents, is quite small for those who adopt from their birth country. Education is inversely related to child's age: that is mothers with a college degree are more likely to adopt younger children. The relationship between mother's education and child's age at adoption is strongest for the foreign-born who adopt in their birth

${ }^{6}$ We omit the estimates for year fixed effects, these are available from the authors upon request. 
country. Finally, family composition seems to have no relationship to child's age. There is no statistically significant association between the mother's married status and the children's age when adopted; similarly, household's income is only negatively associated with children's age at adoption in the case of foreign born parents not adopting in their country of birth. Finally, if other children are present in the household, younger children tend to be adopted. This correlation is strong for all three parental interactions. Note that the countries' fixed effects reflect the estimates in Figure 5A-D, where children adopted from China, Korea, Russia, India and Guatemala tend to be younger when adopted, while children adopted from Mexico and the Philippines tend to be elder.

The estimates in Table 3 implicitly assume that the association between parent characteristics $X$ and the child's age of adoption is constant across all age groups. There is no reason to think this is a valid assumption, if parents have a strong preference for infant children. As an alternative, we estimate the following logit regression

$$
I_{i t}=\theta_{1} X_{i t} \times U S_{i t}+\theta_{2} X_{i t} \times S C_{i t}+\theta_{3} X_{i t} \times D C_{i t}+C^{\prime} \beta+Y^{\prime} \gamma+\varepsilon_{i t}
$$

where $I_{i t}$ is a variable indicating the probability that a child is not an infant, defined in this case as a child who is three or older, at the age of adoption. $I_{i t}$ is not observed, instead we use $I^{\prime}{ }_{i t}$ which takes a value of one if the child was adopted after her third birthday, zero otherwise. Estimates for equation (2) are presented in Table 4.

The estimates suggest a story that is similar to the one revealed in Table 3 with two important exceptions, children adopted by single parents from the same country of birth are 20 percentage points more likely to be three years of age or 
older. In addition, the household's age adjusted income is negatively associated with the probability of adopting a child age three or older. This, together with the negative estimates for the coefficient of mother having a college degree, is suggestive that families with more resources and desirable characteristics are more likely to adopt infants, consistent with the family formation hypothesis. In addition, once that we control for these characteristics, children adopted by parents born in the same country are 70 percentage points more likely to be three or older, children adopted by foreign born parents in a different country are 52 percentage points more likely to be three or older. In summary, not only do differences in the age of adoption persist once one controls for parents characteristics and country of birth, but actually these differences magnify when we compare very young children to all others, again suggesting that parents born in the United States and foreign-born parents adopt very different children. This is especially so when the parent's adopt children in their birth country.

\section{Summary}

The adoption of foreign-born children by parents living in the United States has more than tripled during the last thirty years, and warrants attention from social scientists. In this paper we highlight the importance of understanding both: 1) economic and policy changes in sending countries; and 2) the incentives that different parents may have when adopting a child. Our analysis considers any differences in the adoption process of children abroad by U.S. and foreign-born parents. The estimates presented in here, while only preliminary, show that the 
characteristics of the children differ according to the nationality of the parent: while U.S. born parents tend to adopt babies mostly from Korea, China and Russia; foreign-born parents tend to adopt children of all ages from their country of origin. This suggests that the incentives and reasons to adopt may very well differ across parents in ways that we do not yet understand. 


\section{References}

Child Welfare League of America. 1999. Adoption Facts (accessed 02.15.2009 at http://www.cwla.org/programs/adoption/adoptionfactsheet.htm

Bachrach, Christine A. (1983) Adoption as a Means to family Formation: Data from the National Survey of family Growth. The Journal of Marriage and Family Vol 45(4) Nov 1983 pp. 859-865.

Brooks, Devon, Sigrid James and Richard P. Barth (2002) Preferred Characteristics of Children in the Need of Adoption: Is there a Demand for Available Foster Children? The Social Service Review Vol76(4) Dec 2002 pp. 575-602.

Kossoudji, Sherrrie A. 2008. New Children to the United States: Foreign Born Adoptions in the New Immigrant Survey. Mimeo.

Kreider, Rose M. 2003. Adopted Children and Step Children: 2000. Census 2000 Special Reports.

Plug, Erik (2004) Estimating the Effect of Mother's Schooling on Children's Schooling Using a Sample of Adoptees. American Economic Review Vol 94(1) March 2004 pp. 358-368.

Sacerdote, Bruce (2007) How Large are the Effects from Changes in family Environment? A Study of Korean American Adoptees. Quarterly Journal of Economics Vol 121(1) Feb 2007 pp. 119-158

U.S. Homeland Security. Various Years. The Handbook of Immigration Statistics. 


\section{Figure 1:}

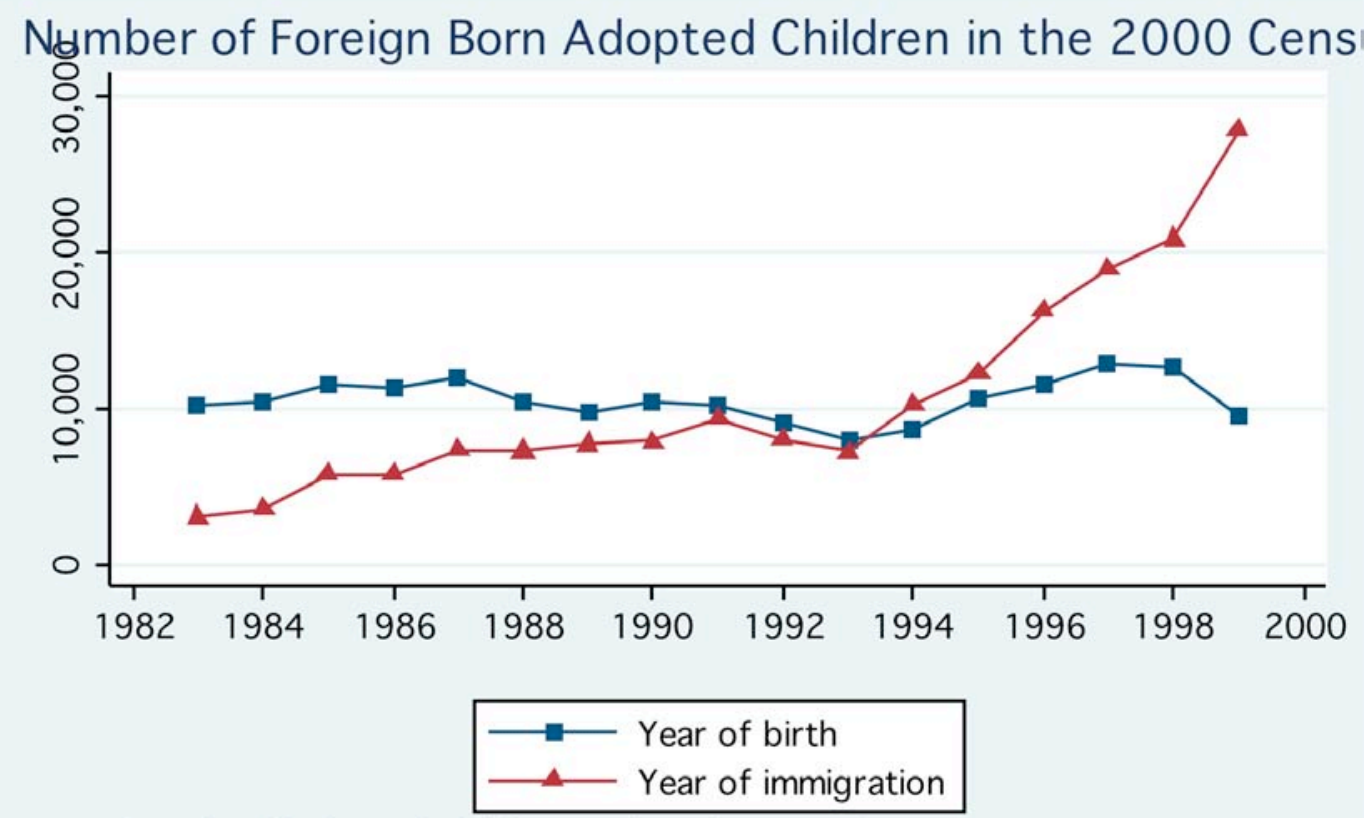

Sample: All adopted children under 18 years of age born before 2000, in the 5\% IPUMS Census 2000

Excludes children who migrated the same year as a parent. 


\section{Figure 2:}

Vumber of Foreign Born Adopted Children in the 2000 Census by parents' place of birth
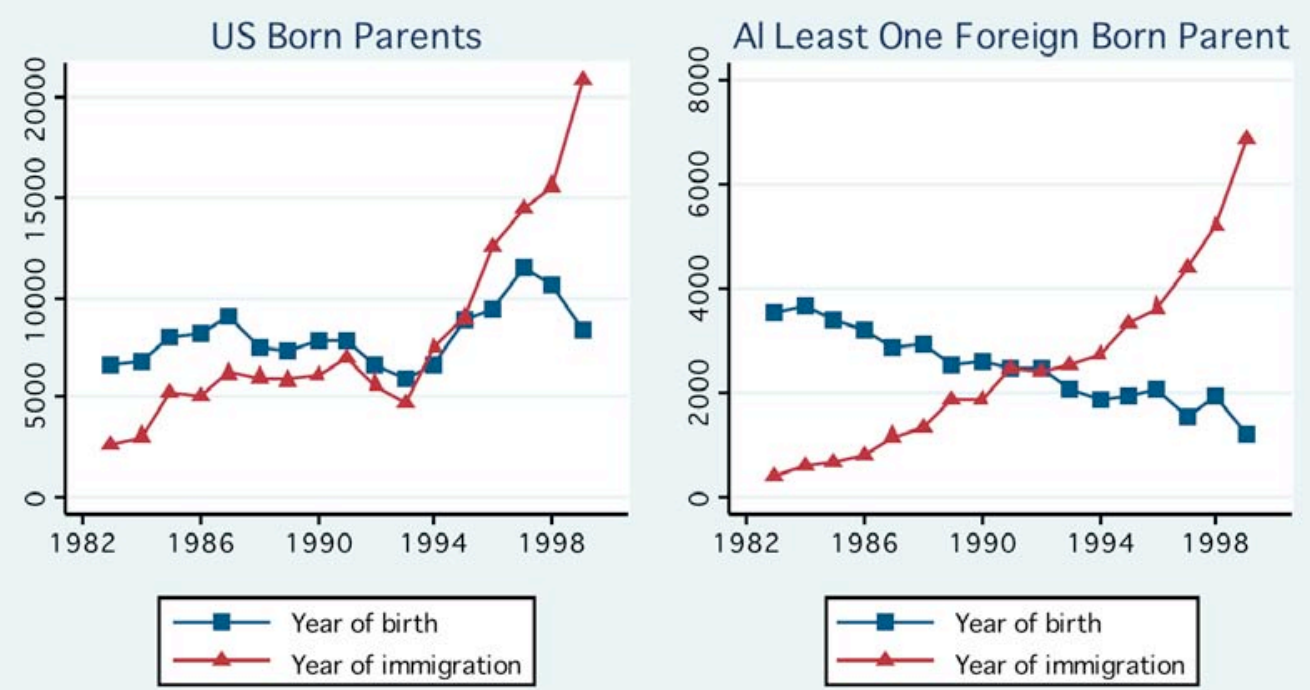

Sample: All adopted children under 18 years of age

born before 2000, in the 5\% IPUMS Census 2000.

Excludes children who migrated the same year as a parent. 


\section{Figure 3:}

\section{Number of Foreign Born Children in the 2000 Census Adopted by Foreign Born Parents}
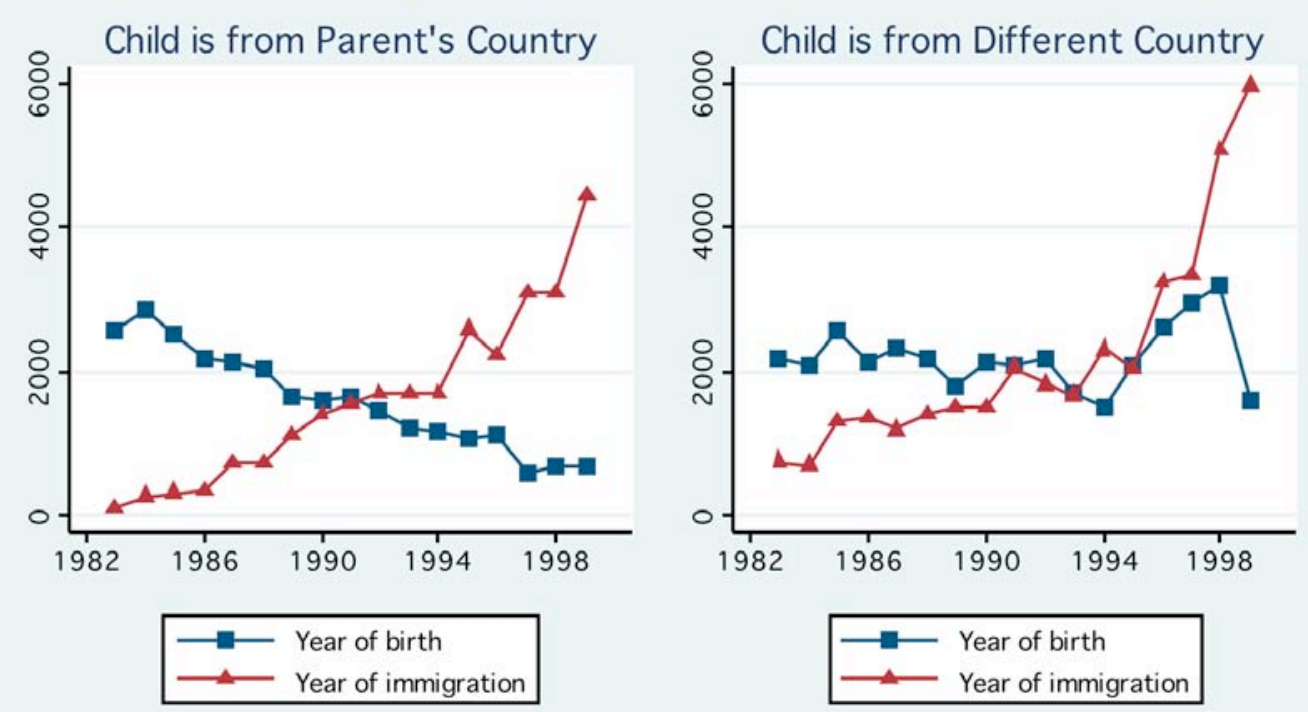

Sample: All adopted children by at least one foreign born parent, under 18 years of age born before 2000, in the 5\% IPUMS Census 2000. Excludes children who migrated the same year as a parent. 


\section{Figure 4:}

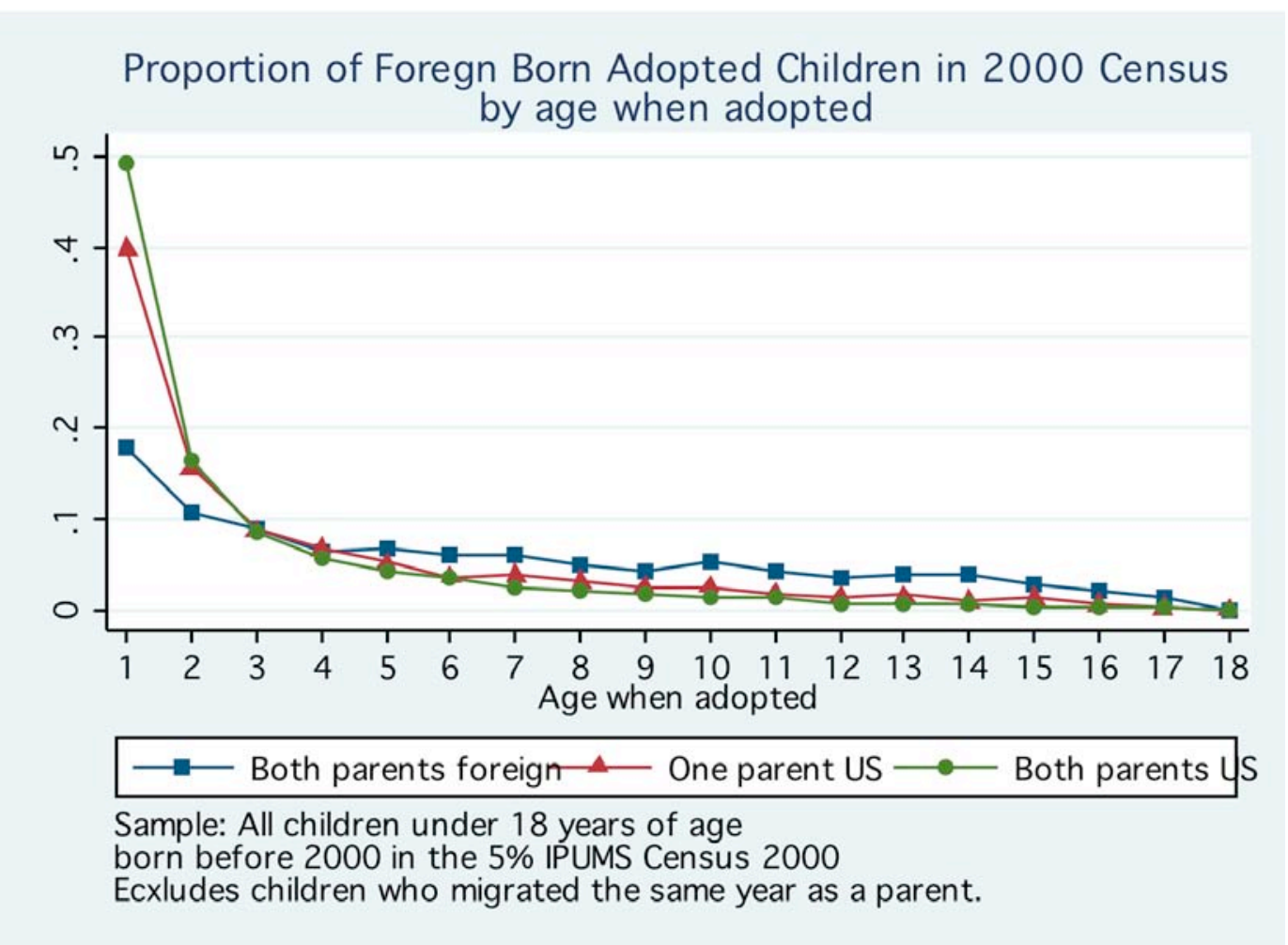




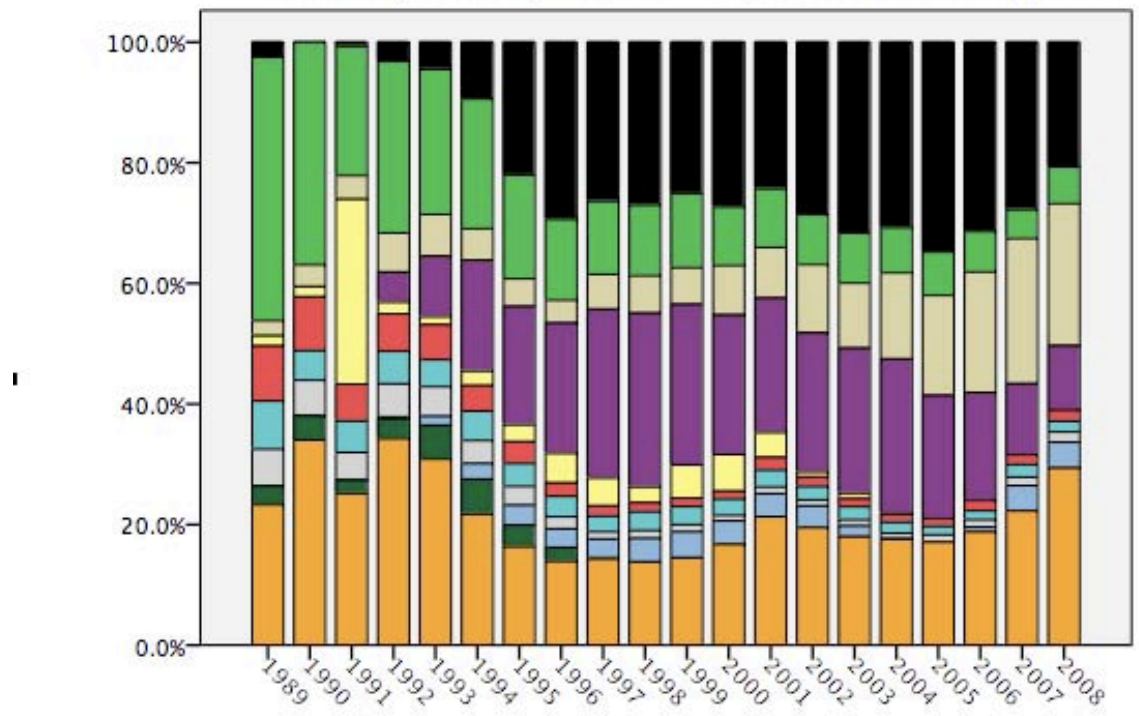

- China

$\square$ Korea

Cuatemala

Russsia

Romania

Colombia

$\square$ India

$\square$ Philippines

$\square$ Vietnam

Daraguay

$\square$ other 
5B: Adopted Foreign Born Children in the U.S. 2000 Census by Source Country

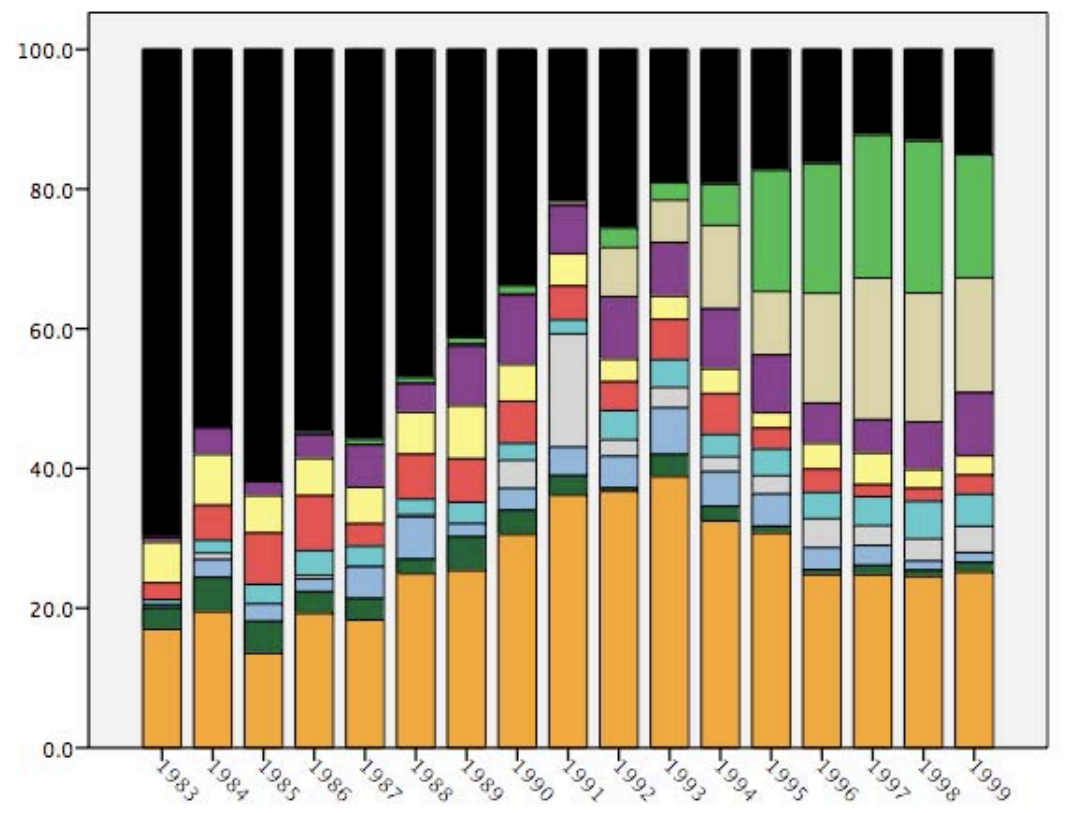

Korea

China

$\square$ Russia

Dindia

Colombia

$\square$ Guatemala

$\square$ Romania

$\square$ Philippines

Germany

$\square$ Allother

Source: U.S. 2000 census. All foreign born adopted under the age of 18 and who did not immigrate same year as parents if parents are foreign born 
5C: Foreign Born Adopted Children in the 2000 Census by Source Country

Both Parents U.S. Born

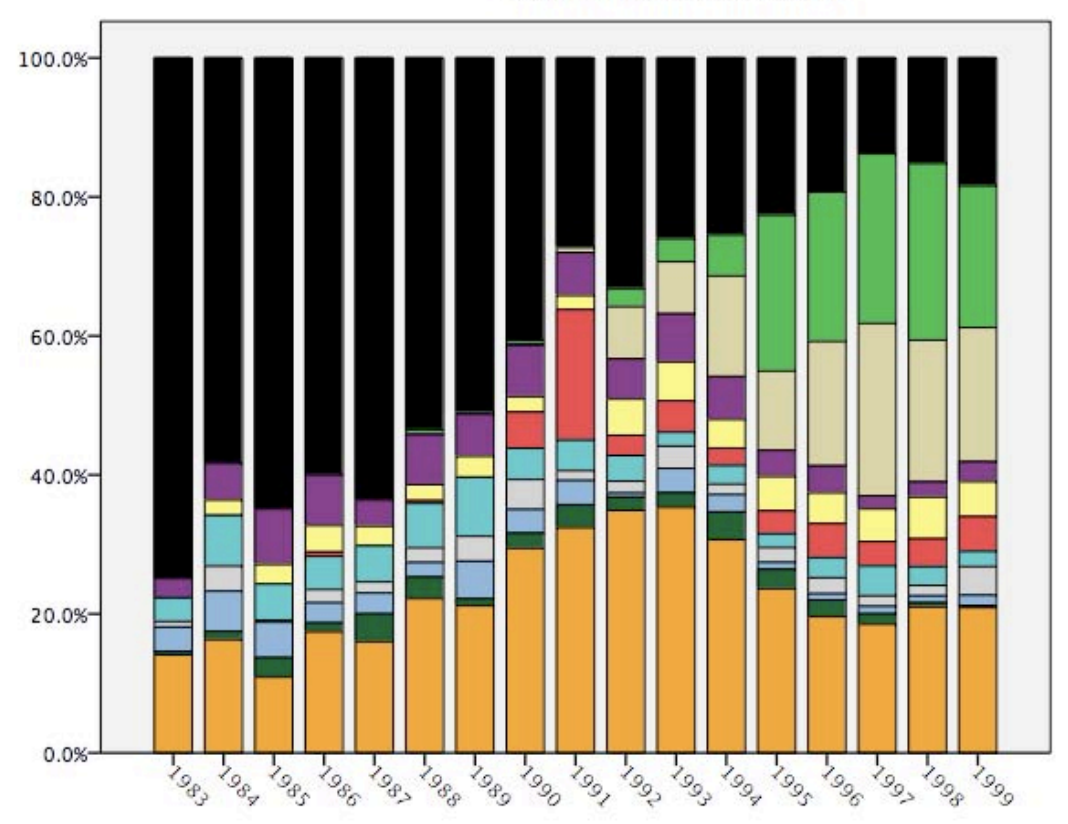

Korea

China

Russia

Tolombia

Domania

Romania

Tindia

Germany

- Cermany

$\square$ Allother

Source: U.S. 2000 Census. Children under the age of 18. 
5D: Adopted Foreign Born Children in the 2000 U.S. Census Both Parents Foreign Born

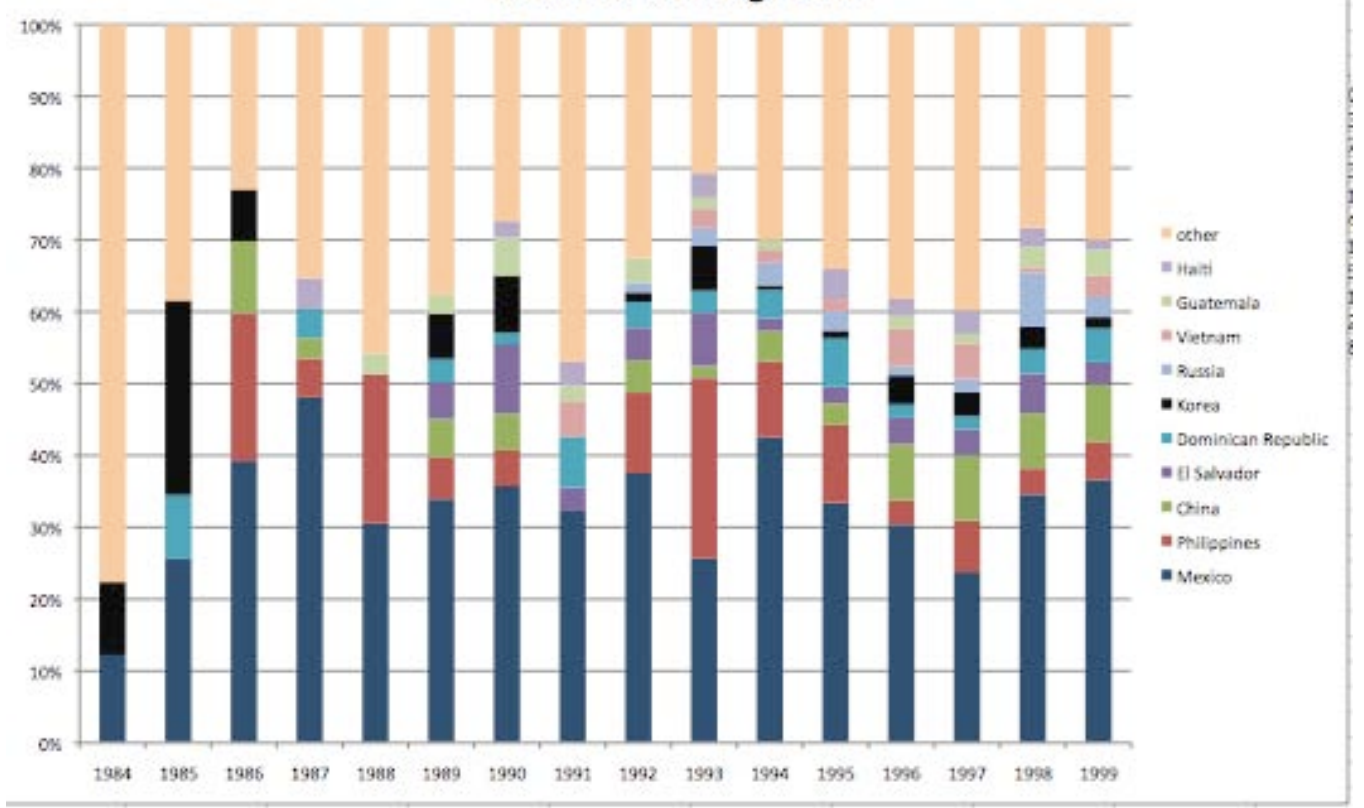




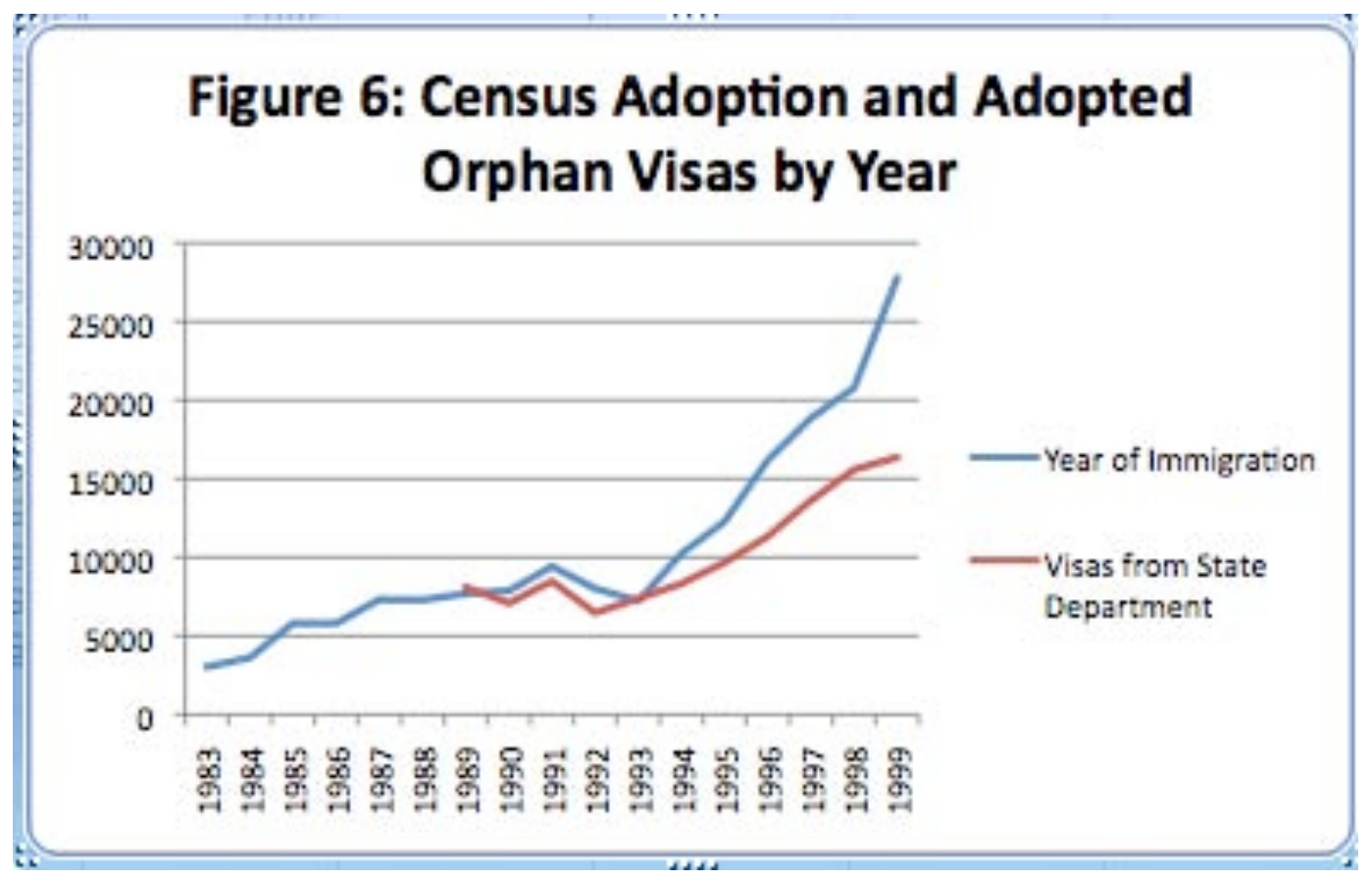


Table 1: Family Characteristics (by Parent's Birth Status)

\begin{tabular}{|c|c|c|c|}
\hline & \multirow{2}{*}{$\begin{array}{c}(1) \\
\text { Both Parents } \\
\text { U.S. Born }\end{array}$} & \multicolumn{2}{|c|}{$\begin{array}{c}(2) \\
\text { At least on Parent Foreign Born }\end{array}$} \\
\hline & & $\begin{array}{l}\text { Adopted from } \\
\text { Same Country }\end{array}$ & $\begin{array}{l}\text { Adopted from } \\
\text { Different Country }\end{array}$ \\
\hline \multirow[t]{2}{*}{ Father's Age Adoption } & 40.1 & 39.4 & 41.2 \\
\hline & $(0.018)$ & $(0.056)$ & $(0.062)$ \\
\hline \multirow[t]{2}{*}{ Mother's Age Adoption } & 38.9 & 38.0 & 39.5 \\
\hline & $\begin{array}{c}(0.016) \\
0.54\end{array}$ & $\begin{array}{c}(0.050) \\
0.27\end{array}$ & $\begin{array}{c}(0.055) \\
0.57\end{array}$ \\
\hline Proportion College, Father & $(0.001)$ & $(0.003)$ & $(0.004)$ \\
\hline \multirow[t]{2}{*}{ Proportion College, Mother } & 0.58 & 0.25 & 0.52 \\
\hline & $(0.001)$ & $(0.003)$ & $(0.004)$ \\
\hline Family Annual Income & $\begin{array}{l}\$ 106,899 \\
(236)\end{array}$ & $\begin{array}{l}\$ 68,231 \\
(409)\end{array}$ & $\begin{array}{l}\$ 107,013 \\
(808)\end{array}$ \\
\hline \multirow[t]{2}{*}{ Age Adjusted Income Decile } & 7.1 & 5.6 & 6.9 \\
\hline & $(0.007)$ & $(0.018)$ & $(0.022)$ \\
\hline \multirow[t]{2}{*}{ Proportion Single, Mother } & 0.13 & 0.13 & 0.10 \\
\hline & $(0.001)$ & $(0.002)$ & $(0.002)$ \\
\hline \multirow[t]{2}{*}{ Proportion Single, Father } & 0.03 & 0.04 & 0.02 \\
\hline & $(0.000)$ & $(0.001)$ & $(0.001)$ \\
\hline \multirow[t]{2}{*}{$\begin{array}{l}\text { Proportion with Biological } \\
\text { Children in HH }\end{array}$} & 0.15 & 0.20 & 0.19 \\
\hline & $(0.001)$ & $(0.002)$ & $(0.003)$ \\
\hline \multirow[t]{2}{*}{$\begin{array}{l}\text { Proportion with Other } \\
\text { Children in Household }\end{array}$} & 0.40 & 0.36 & 0.40 \\
\hline & $(0.001)$ & $(0.003)$ & $(0.004)$ \\
\hline $\mathrm{N}$ & 6,770 & 1,263 & 711 \\
\hline Weighted N & 137,156 & 26,967 & 15,119 \\
\hline
\end{tabular}

Sample: All children under 18 years of age, born before 2000 in the 5\% IPUMS Census 2000. Excludes children who migrated at the same time of the parent. 
Table 2. Child Characteristics (by Parent's Birth Status)

\begin{tabular}{|c|c|c|c|}
\hline & \multirow{2}{*}{$\begin{array}{c}(1) \\
\text { Both Parents } \\
\text { U.S. Born }\end{array}$} & \multicolumn{2}{|c|}{$\begin{array}{c}(2) \\
\text { At least on Parent Foreign Born }\end{array}$} \\
\hline & & $\begin{array}{l}\text { Same } \\
\text { Country }\end{array}$ & $\begin{array}{l}\text { Different } \\
\text { Country }\end{array}$ \\
\hline Age when Adopted & 3.1 & 6.5 & 3.8 \\
\hline Proportion Female & $\begin{array}{c}(0.009) \\
0.61\end{array}$ & $\begin{array}{c}(0.028) \\
0.55\end{array}$ & $\begin{array}{c}(0.028) \\
0.60\end{array}$ \\
\hline Proportion Hispanic/Latino & $\begin{array}{c}(0.001) \\
0.19\end{array}$ & $\begin{array}{c}(0.003) \\
0.48\end{array}$ & $\begin{array}{c}(0.004) \\
0.21\end{array}$ \\
\hline Proportion Asian & $\begin{array}{c}(0.001) \\
0.52\end{array}$ & $\begin{array}{c}(0.003) \\
0.32\end{array}$ & $\begin{array}{c}(0.003) \\
0.42\end{array}$ \\
\hline Proportion Black & $\begin{array}{c}(0.001) \\
0.03\end{array}$ & $\begin{array}{c}(0.003) \\
0.09\end{array}$ & $\begin{array}{c}(0.004) \\
0.06\end{array}$ \\
\hline & $(0.000)$ & $(0.002)$ & $(0.002)$ \\
\hline $\begin{array}{l}\mathrm{N} \\
\text { Weighted N }\end{array}$ & $\begin{array}{c}6,770 \\
137,156\end{array}$ & $\begin{array}{c}1,263 \\
26,967\end{array}$ & $\begin{array}{c}711 \\
15,119\end{array}$ \\
\hline
\end{tabular}

Sample: All children under 18 years of age, born before 2000 in the 5\% IPUMS Census 2000. Excludes children who migrated at the same time of the parent. 
Table 3. OLS Regression Dependent Variable: Child's Age When Adopted

\begin{tabular}{|c|c|c|c|}
\hline & $\begin{array}{c}\text { (1) } \\
\text { U.S. Born }\end{array}$ & $\begin{array}{c}(2) \\
\text { Foreign Born } \\
\text { Same } \\
\text { Country } \\
\end{array}$ & $\begin{array}{c}(3) \\
\text { Foreign Born } \\
\text { Different } \\
\text { Country } \\
\end{array}$ \\
\hline Group Intercept & & $\begin{array}{l}7.816^{* *} \\
(0.973)\end{array}$ & $\begin{array}{l}4.073^{* *} \\
(0.979)\end{array}$ \\
\hline Mother, Age & $\begin{array}{l}0.192^{* *} \\
(0.012)\end{array}$ & $\begin{array}{l}0.072^{* *} \\
(0.018)\end{array}$ & $\begin{array}{l}0.130^{* *} \\
(0.025)\end{array}$ \\
\hline Mother, College Grad & $\begin{array}{c}-0.934^{* *} \\
(0.141)\end{array}$ & $\begin{array}{c}-1.855^{* *} \\
(0.549)\end{array}$ & $\begin{array}{c}-0.681^{* *} \\
(0.351)\end{array}$ \\
\hline Single Parent & $\begin{array}{c}-0.048 \\
(0.159)\end{array}$ & $\begin{array}{c}0.501 \\
(0.465)\end{array}$ & $\begin{array}{c}0.299 \\
(0.531)\end{array}$ \\
\hline Age Adjusted Income Decile & $\begin{array}{c}0.000 \\
(0.003)\end{array}$ & $\begin{array}{c}-0.006 \\
(0.007)\end{array}$ & $\begin{array}{c}-0.020^{* *} \\
(0.006)\end{array}$ \\
\hline Other Children at Adoption & $\begin{array}{c}-0.714^{* *} \\
(0.101)\end{array}$ & $\begin{array}{c}-0.909 * * \\
(0.347)\end{array}$ & $\begin{array}{c}-0.460 * * \\
(0.205)\end{array}$ \\
\hline Korea & & $\begin{array}{c}-0.095 \\
(0.191)\end{array}$ & \\
\hline China & & $\begin{array}{c}-3.330^{* *} \\
(0.170)\end{array}$ & \\
\hline Russia & & $\begin{array}{c}-1.443^{* *} \\
(0.227)\end{array}$ & \\
\hline Mexico & & $\begin{array}{l}0.582^{* *} \\
(0.226)\end{array}$ & \\
\hline India & & $\begin{array}{l}-0.728^{*} \\
(0.388)\end{array}$ & \\
\hline Colombia & & $\begin{array}{c}0.094 \\
(0.201)\end{array}$ & \\
\hline Guatemala & & $\begin{array}{c}-1.586^{* *} \\
(0.283)\end{array}$ & \\
\hline Romania & & $\begin{array}{c}-0.839 * * \\
(0.224)\end{array}$ & \\
\hline Philippines & & $\begin{array}{c}0.516^{*} \\
(0.313)\end{array}$ & \\
\hline $\mathrm{R}-2$ & & 0.296 & \\
\hline $\mathrm{N}$ & & 6,624 & \\
\hline
\end{tabular}

** Statistically significant at 5\% * Statistically significant at 10\%.

All regressions include year of immigration fixed effects

Sample: All children under 18 years of age, born before 2000 in the 5\% IPUMS

Census 2000. Excludes children who migrated at the same time of the parent. 
Table 4. Logit Regression, Dependent Variable: Probability Child is Adopted at Age Three or Older. Coefficients represent marginal effects

\begin{tabular}{|c|c|c|c|}
\hline & (1) & $(2)$ & (3) \\
\hline & & \multicolumn{2}{|c|}{ At least 1 Parent Foreign Born } \\
\hline & US Citizen & Same & Different \\
\hline & & Country & Country \\
\hline \multirow[t]{2}{*}{ Group Intercept } & & $0.701^{* *}$ & $0.525^{* *}$ \\
\hline & & $(0.028)$ & $(0.049)$ \\
\hline \multirow[t]{2}{*}{ Mom Age in US } & $0.029^{* *}$ & $0.005^{*}$ & $0.018^{* *}$ \\
\hline & $(0.002)$ & $(0.003)$ & $(0.004)$ \\
\hline \multirow[t]{2}{*}{ Mom College Grad } & $-0.119^{* *}$ & $-0.154^{* *}$ & $-0.092^{* *}$ \\
\hline & $(0.021)$ & $(0.054)$ & $(0.042)$ \\
\hline \multirow[t]{2}{*}{ Single Parent } & -0.032 & $0.198^{* *}$ & 0.084 \\
\hline & $(0.028)$ & $(0.073)$ & $(0.108)$ \\
\hline \multirow[t]{2}{*}{ Age Adjusted Income Decile } & $-0.001^{*}$ & -0.001 & $-0.004^{* *}$ \\
\hline & $(0.000)$ & $(0.001)$ & $(0.001)$ \\
\hline \multirow[t]{2}{*}{ Other Children when Adoption } & $-0.028^{*}$ & $-0.086^{* *}$ & -0.020 \\
\hline & $(0.015)$ & $(0.034)$ & $(0.036)$ \\
\hline \multirow[t]{2}{*}{ Korea } & & $-0.093^{* *}$ & \\
\hline & & $(0.027)$ & \\
\hline \multirow[t]{2}{*}{ China } & & $-0.438^{* *}$ & \\
\hline & & $(0.017)$ & \\
\hline \multirow[t]{2}{*}{ Russia } & & $-0.121^{* *}$ & \\
\hline & & $(0.032)$ & \\
\hline \multirow[t]{2}{*}{ Mexico } & & $0.066^{*}$ & \\
\hline & & $(0.034)$ & \\
\hline \multirow[t]{2}{*}{ India } & & $-0.127^{* *}$ & \\
\hline & & $(0.053)$ & \\
\hline \multirow[t]{2}{*}{ Colombia } & & -0.017 & \\
\hline & & $(0.034)$ & \\
\hline \multirow[t]{2}{*}{ Guatemala } & & $-0.241^{* *}$ & \\
\hline & & $(0.030)$ & \\
\hline \multirow[t]{2}{*}{ Romania } & & -0.027 & \\
\hline & & $(0.047)$ & \\
\hline \multirow[t]{2}{*}{ Philippines } & & $0.134^{* *}$ & \\
\hline & & $(0.048)$ & \\
\hline Pseudo R-2 & & 0.180 & \\
\hline $\mathrm{N}$ & & 6,624 & \\
\hline
\end{tabular}

** Statistically significant at $5 \%$ * Statistically significant at $10 \%$.

All regressions include year of immigration fixed effects 
Sample: All children under 18 years of age, born before 2000 in the 5\% IPUMS Census 2000. Excludes children who migrated at the same time of the parent. 